\title{
VYBRANÉ ZDRAVOVĚDNÉ ASPEKTY CESTOPISU KRYŠTOFA HARANTA Z POLŽIC A BEZDRUŽIC
}

\author{
DAVID TOMÍČEK
}

\section{SELECT PARTS OF THE TRAVEL DIARY OF KRYŠTOF HARANT OF POLŽICE AND BEZDRUŽICE DEALING WITH HEALTH AND HYGIENE}

Kryštof Harant's travel diary (1608) includes not only descriptions of this Czech noble's authentic experiences, but also a wide array of information pertaining to places he visited. This article focuses on some aspects of contemporary medicine, medical education, and materia medica. Alongside some exotic substances, most attention is paid to plaque epidemics and preventive measures designed to prevent their spread.

Keywords: $16^{\text {th }}$ century - travel diary - medicine - Venice - opium - mummies

DOI: $10.14712 / 23365730.2018 .24$

Cestopisné líčení pouti do Svaté země a Egypta, které sepsal a roku 1608 nechal vytisknout Kryštof Harant z Polžic a Bezdružic, ${ }^{1}$ patří k dobře známým pramenům předbělohorské doby. ${ }^{2}$ Jde o mimořádné literární dílo kombinující prvky autorského vyprávění o událostech s encyklopedickým výkladem reálií navštívených míst. V následujícím textu se pokusím vyložit vybraná témata vztahující se k dobové zdravovědě. Věnovat se budu otázkám spojeným s ochranou před morovou nákazou a dobovou farmakologií, respektive materia medica. Do této oblasti byly ještě v raném novověku standardně řazeny substance veskrze roztodivné a především pestré.

Kryštof Harant byl nepochybně seznámen se skutečností, že podstatou morového onemocnění je zkažený, či lépe řečeno otrávený vzduch. Svěží a čisté ovzduší naopak spojoval s nezávadnou a zdraví prospěšnou lokalitou. O jihotyrolském Brixenu napsal, že je vystavěn na „místě rozkošném a zdravém“", nebot' se v jeho okolí „velmi mírné povětři nacházi“" 3 Zdravé ovzduší přisoudil i Benátkám, kde si povšiml značného počtu věkovitých lidí. ${ }^{4}$ Ve městě na laguně také na vlastní kůži zažil nepřijemnosti spojené s realizací opatření ukotvených v zásadách kolektivní ochrany před nákazou, konkrétně s kontrolou zdravotního

1 Kryštof Harant z PolžIc a BezdružIc, Putování aneb Cesta z Království českého do města Benátek, odtud po moři do země Svaté, země Judské, a dále do Egypta a velikého města Kairu, potom na horu Oreb, Sinai a svaté panny Kateřiny, v pusté Arábii ležicí, na dva díly rozdělená, Praha 1608.

2 Marie Koldinské, Kryštof Harant z Polžic a Bezdružic. Cesta intelektuála k popravišti, Praha - Litomyšl 2004, s. 62-190.

3 K. Harant, Putování, I, s. 9.

4 Tamtéž, s. 18. 
pasu, jenž byl vystaven v Tridentu pouze na jméno společníka Heřmana Černína. A právě v souvislosti s popisem jihotyrolského centra Harant zaznamenal své postřehy o těchto zásadách, včetně čtyřicetidenní izolace podezřelých osob, a uvedený postup pojmenoval jako zvyk dodržovaný v ,zemích vlašských a jiných okolních“. 5

V závěru 16. století Benátky patřily $\mathrm{k}$ městům, v nichž měla institucionalizace kolektivních opatření proti morové nákaze více jak stoletou tradici. První dočasný úřad mající za cíl chránit obyvatele před nákazou zde byl zrrízen v podobě tř́ičlenné komise již 8. března 1348, první stálý úřad mající v gesci otázky veřejného zdraví pak 7 . ledna 1486. Trojice členů tohoto stálého sboru se mohla honosit titulem Provedittori di sanita. ${ }^{6}$ Harant ve výčtu benátských úřadů zmiňuje dvě skupiny úředníků, jež měly co do činění s otázkami lékařství a ochrany zdraví. Zatímco Signori de notte criminali se věnovali závažným trestným činům, mezi nimiž český cestovatel uvádí i neohlášené přechovávání a léčbu malomocných, Signori della sanita zodpovídali za realizaci opatření vedoucích k ochraně před nákazou. Není bez zajímavosti, že do jejich gesce spadala i reglementace prostituce. Harant výslovně píše: „Páni nad zdravím totiž dohlídají, aby se nečistotau k nakažení města přičina nedala, a jestli kdo nakažený, časně jej do míst a špitálìv k tomu nařizených dají. Ti také pozor mají na lékaře a dryáčníky. A mají počet všech cortesan, to jest obecnich nevěstek pro plat, kterýž od nich berau, aby řád mezi nimi byl, jichžto saudcové jsau. "7 Kolektivní opatření pěstovaná v severoitalských městech se v zásadě opírala především o přísnou kontrolu pohybu obyvatelstva, společné pohřbívání obětí morových epidemií, izolaci nemocných v lazaretech, bezplatnou lékařskou službu nemocným a zajišt'ování životního minima pro obyvatele, kteří v důsledku karanténních opatření přišli o zdroje obživy. ${ }^{8}$

Dle vyprávění Kryštofa Haranta morová nákaza způsobila zkázu kláštera sv. Mikuláše na Kypru. V době Harantovy pouti byl již klášter pustý, nicméně ještě třicet let nazpět zde měla působit komunita mnichů, strádající přítomností početných ,hadů a žižal rozlišných" žijících v okolí. Mniši proto chovali kočky cvičené k lovu jedovatých plazů. Kočky údajně každé ráno opouštěly klášter, zabíjely hady a za zvuku zvonce se kolem poledního vracely do kláštera na krmení. Podobně vypadal i jejich odpolední program až do dnů, kdy do kláštera pronikla zmiňovaná nákaza, jež zapříčinila zánik zdejší komunity. Harant ve svém cestopise uvedl tvrzení, že zdrojem morové nákazy byly právě vycvičené kočky, které ,od těch hadi̊v jedem nakaženy byly, od nichž i mniši se nakazili, že na větším díle pomřeli a ostatek jích pryč ujelo, kláštera pustého zanechavše, kterýž tak až podnes zůstává'. 9

Vzdělaný cestovatel patrně vnímal jako přirozené, že mezi hadím jedem a morovou nákazou existuje genetická souvislost. Koneckonců latinské texty o moru ze 14. a 15. století dobře ukazují, že soudobá lékařská elita chápala nákazu jako smrtelný jed svého druhu ${ }^{10}$

5 Tamtéž, s. 12.

6 Carlo M. Cipolla, Public Health and the Medical Proffesion in the Renaissance, London - New York - Melbourne 1976, s. 11-12.

7 K. Harant, Putování, I, s. 37.

8 Sheldon WatTs, Epidemics and History. Disease, Power, and Imperialism, New Haven - London 1999, s. 16-17. Blíže ke kolektivním i individuálním opatřením viz Karel ČERNÝ, Mor 1480-1730. Epidemie v lékařských traktátech raného novověku, Praha 2014, s. 292-385.

9 K. Harant, Putování, I, s. 89-90.

10 David ToмíčEK, Mor a lékařská literatura pozdního středověku, Theatrum historiae 11, 2012, s. 35-45. 
a toto přesvědčení bylo vlastní i pozdějším textům. Lékař Václav Maxmilián Ardensbach z Ardensdorfu v díle Armamentarium antiloimicum z roku 1679 napsal: ,Ačkoliv jest morová rána jed, nic méně žádný jed není tak veliký, tak zlý a tak hrozný, jako tento." ${ }^{11}$ Kočkám, psům, ale i jinému domácímu zvířectvu jako potenciálním přenašečům nákazy věnovaly pozornost také raně novověké morové řády, jež nařizovaly, aby byla tato zviŕrata pochytána a utracena. ${ }^{12} \mathrm{~V}$ českém prostředí o kočkách a psech v souvislosti s morovou nákazou psal např́klad lékař Bartholomeus Schwalb v díle Nařizení a správa velmi potřebná z roku 1598. Uvedl, že „častokrát od sausedův jed s sebau prininášejí, jakž to mnohokráte zkušeno jest ${ }^{\text {“ }}{ }^{13} \mathrm{~V}$ podobném duchu hovoří i článek morového řádu vydaného místodržícími Království českého roku 1613, v němž se píše: „Nečistých hovad v domích zbytečně aby žádný nechoval, jako dobytka svinského, koček, smrdutých kozlů, psů nečistých; nebo taková hovádka snadno s sebou nakažení z domuov do domuov přenášeji." "14

Zatímco kočky či jedovaté hady Kryštof Harant do příčinného vztahu s morovou nákazou kladl, v př́ípadě hlodavců tak neučinil, což u raně novověkého autora překvapivé není. $\mathrm{S}$ životem hlodavců si nicméně spojil zajímavou biologickou souvislost, a to konkrétně skutečnost, že se údajně rodí z rozličného odpadu a špíny, jež se v nepř́ijemném množství koncentruje v prostorách lodního podpalubí. ${ }^{15}$ Špína a zápach v útrobách korábu plujícího z Benátek východním středomořím Haranta dráždila a na stránkách svého cestopisu o tomto nepř́ijemném zážitku učinil zmínku. ${ }^{16}$ Lze se jen skutečně pouze hypoteticky tázat, zda by tyto z podstaty nečisté hlodavce, charakterizované jako „veliké myši, kteréž u nás německé slovau“ ${ }^{17}$ jejichž takřka intimní přítomnost mu plavbu nepochybně krajně znepř́jemňovala, spojil s nákazou, pokud by se byla vyskytla na palubě lodi. Odpověd' se nedovíme. Platí nicméně tvrzení, že nečistota a zápach - dle Kryštofa Haranta vlastní plodivé prostředí lodních hlodavců - evokovaly v myslích jeho současníků samotnou př́činu morové nákazy. ${ }^{18}$

Zápach byl podle jeho tvrzení charakteristický pro alexandrijský kanalizační systém. Kryštof Harant uvádí, že do sklepů zdejších obydlí proniká kalná voda nilského ramene, která se zde usazuje a způsobuje „smrad a puch, kterýž zlé povětř́i čini“". ${ }^{19}$ Jako závažný problém vnímal český cestovatel skutečnost, že lidé zdejší nezdravou vodu pijí, v důsledku čehož u nich propukají horečnatá onemocnění. Za nejnebezpečnější místo z hlediska morní nákazy však považoval lidnatou Káhiru, o níž dle zpráv zdejších křest’anů napsal, že zde epidemie propukají téměř každoročně, minimálně pak jednou za tři roky. Úmrtnost během těchto epidemií údajně dosahovala až těžko uvěřitelného půl milionu osob. K těmto

11 Václav Maxmilián Ardensbach z Ardensdorfu, Armamentarium antiloimicum, Praha 1679, s. 2. Viz též Filip HrBeK, Českojazyčné morové tisky raného novověku, Ústecký sborník historický - Supplementum (v tisku).

12 Carlo M. CippolA, Fighting the Plague in 17th century Italy, Madison 1999, s. 74-75.

13 Bartholomeus Schwalb, Nařizeni a správa velmi potrebná, Praha 1598, f. $\mathrm{B}_{3} \mathrm{r}$.

14 Václav Schulz (ed.), Př́spěvky k déjinám moru v zemích českých z let 1531-1746, Praha 1902, s. 63. K morovým řádům viz též Pavla JiRKovÁ, Ustanovený řád: Koncept morového řádu pro Čechy v kontextu normativních textů středni Evropy z prelomu 70. a 80. let 17. století, Folia Historica Bohemica 31/1, 2016, s. $25-51$.

15 K. Harant, Putování, I, s. 113.

16 Tamtéž, s. 59.

17 Tamtéž.

18 Carlo M. Cippola, Miasmas and Disease. Public Health and the Environment in the Pre-industrial Age, New Haven - London 1999, s. 7. K otázkám spojeným s recepcí zápachu viz též Alain CorBin, Narcis a miasma. Pach a společenské predstavy 18. a 19. století, Praha 2004.

19 K. Harant, Putováni, II, s. 257. 
drastickým počtům prý výrazně přispívalo takřka iracionální chování zdejších obyvatel, kteří byli podle Harantových slov „nakvašeni bludem“ o nevyhnutelnosti předem daného lidského osudu. Autor doslova píše: „A tak jedni druhých se v čas moru neštití, anobrž jakkoli kdo nakažen jest, k němu směle chodí, s ním obcuji, šatů po umrlém uživají, je svobodně mezi jinými věcmi prodávaji a nikoliv pro mor z domu, ovšem z města se nehýbají. Odkudž pocházi to, že mohauce za času nakaženi morni pretrhnauti rozšafností a šetřením své životy zachovávati, však svévolně se do nebezpečenství dávajíce, jako hovada zhusta mrau, se káceji. " 20

Projevy nábožensky motivovaného fatalizmu ve vztahu k morové nákaze nebyly charakteristické jen pro islámské prostředí. Zaznamenaly je např́klad členové jezuitského řádu v Praze roku $1569^{21}$ a jako doklad ryzího křest’anského chování k nemocným je prezentoval ve svém tištěném dialogu z osmdesátých let 16 . století také katolický duchovní Jan z Bakova. Jak napovídá již titul Sedlák povycvičený rozmlouvání s doktorem lékařským o moru maje, že od morových bolestí žádného nakaženi není, dovozuje, vymezuje se dílo proti zásadám karanténních opatření, především proti izolaci nemocných. Podobně jako Kryštof Harant klade bakovský farář Jan karanténní pravidla do souvislosti s italským prostřeedím a hovoří o nich s despektem jako o „vlašském obyčeji “. 22 Harant nicméně na stránkách svého cestopisu podává ještě jeden príklad úspěšného boje s morovou nákazou, který měl být charakteristický pro soudobou Čínu. Čínská společnost je v jeho podání natolik „stabilizovaná“, že v ní prakticky neexistuje zahálka, nebot’ zde (nuceně) pracují i tělesně postižení lidé. Jako př́klad uvádí město Kanton, v němž ruční mlýnky obsluhuje na čtyři tisíce slepců. Fascinován tímto úspěchem český cestovatel tvrdil: „Z té př́činy neni se čemu diviti, že v té zemi ani vjiných okolních nikdy moru nebývá, ani tak mnohých nemocí jako u nás, když to tak v̌̌e středmostí svau a zdravým povětř́m i také ustavičným pracováním oni premáhaji. “23

Ve svém cestopise věnoval Kryštof Harant pozornost zahradám, a to jak v Evropě, tak v zemích Předního východu. Zpravidla jej upoutala jejich krása či uspořádání, př́ípadně skutečnost, že jsou v nich pěstované nějaké vzácné, exotické či dokonce divotvorné rostliny. Zámecká zahrada v bavorském Landshutu tak podle jeho slov umožňovala mj. pozorovat „,šelijaká divná koření, kvití a byliny““. ${ }^{24}$ Zcela nepochybně jej pak zaujala botanická zahrada při lékařské fakultě $\mathrm{v}$ italské Padově. Botanické zahrady patřily vedle piteven a observatoří mezi nově etablované formy výukových prostor, jež začaly být v univerzitním prostředí zřizovány v průběhu raného novověku. ${ }^{25}$ Výjimečně uspořádaná zahrada $\mathrm{v}$ Padově byla založena roku 1545 a je považována za nejstarší univerzitní botanickou zahradu v Evropě ${ }^{26}$ Harant o této zahradě s obdivem uvedl, že byla s velkými náklady zř́zena ,pro

20 Tamtéž, s. 217.

21 A. Lynn Martin, Plague? Jesuit Accounts of Epidemic Disease in the 16th Century, Kirkville 1996, s. 41-43. $\mathrm{K}$ problematice postoje členů jezuitského řádu k morovým epidemiím viz též Karel ČERNÝ - Jiří M. HAVLíK, Jezuité a mor, Praha 2008.

22 Jan z BAKova, Sedlák povycvičený rozmlouváni s doktorem lékařským o moru maje, že od morových bolestí žádného nakažení není, dovozuje, Praha [1582?], f. 24v.

23 K. Harant, Putováni, II, s. 160.

24 K. Harant, Putování, I, s. 3.

25 Peter Burke, Společnost a vědění. Od Guttenberga k Diderotovi, Praha 2007, s. 59.

26 Maurizio Rippa Bonnati - Vittorio Dal Piaz, The Design and Form of the Padua Horto Medicinale, in: Alessandro Minelli (ed.), The Botanical Garden of Padua 1545-1995, Venezia 1995, s. 33-55. 
mládež a studenty umění lékařského a apatykářského, aby tu jako na theatrum domácí i prespolni byliny vlastně a očitě znáti se učili, jích moc a užitek věděli““. ${ }^{27}$ Dále uvedl, že kromě zahradníků na místě působí také dva profesoři, kteří minimálně dvakrát týdně mezi záhony studentům demonstrují botanickou látku. Nad branou do zahrady byl napsaný zahradní raád, jehož sedm latinsky psaných bodů vztahujících se k chování návštěvníků Harant ve svém cestopise uvedl v originále i českém překladu. ${ }^{28}$

Zatímco Padovu a její univerzitu Harant líčil jako významné centrum studia lékařských věd, z hlediska znalosti a dostupnosti léčiv vyzdvihl na přední místo jednoznačně Káhiru. Krámky zdejších židovských lékárníků a „materialistư“ měly být bezkonkurečně nejlépe vybavené, přičemž žádný křest'anský apatykář se jejich provozovatelům ve znalostech jednotlivých druhů léčiv nemohl rovnat. Český cestovatel se v zásadě nemýlil, když tvrdil, že Židé kromě nebývalého množství nejrůznějších léčiv vlastnili také cenné arabsky psané lékařské knihy a herbáře, jmenovitě díla Hippokratova, Galénova, Rhazésova a Serapionova. Ve výčtu lékařských autorit zmínil také Aristotela a Platóna. ${ }^{29} \mathrm{Z}$ těchto pro Evropana nepř́stupných knih čerpali své znalosti farmakologie i lékařského umění. O Arabech na jiném místě uvedl, že bývali velkými milovníky filozofie a jejich učenci jsou dodnes ctěni jako přední oborové autority, a to nejen v medicíně, ale i v okultních vědách a astrologii. ${ }^{30}$ Zajímavou poznámku Harant učinil také o Egypt’anech, respektive obyvatelích Alexandrie. Zdejší domy mají ploché střechy, kterých lidé využivají jako prríjemně chladných míst pro noční odpočinek, ale též pro pozorování hvězd. Z tohoto důvodu prý „Alexandrijští nad jiné národy nejlepši hvězdárí byli, protože lehajice a vstávajíce, aneb v myšlenkách ležice, vídali hvězdy cursum zodiacum vycházením i zacházením vykonávati““.31

Navštívené země Předního východu byly ale především bohatým rezervoárem živočichů, rostlin i jiných př́rodnin s divotvornými či zázračnými účinky, jež byly tradičně využívány v evropském lékařství. Kryštof Harant jim ve svém cestopise věnoval zaujatou pozornost a nezř́dka učinil poznámku o tom, že je daná skutečnost - rostlina, živočich či substance známá v Praze, respektive na císařském dvoře. Mezi takové substance patří na prvním místě mumie, o nichž se obsáhle rozepsal ve druhé části cestopisu. Ve výkladech o podstatě látky známé jako mumie nepanovala shoda, jak ukazuje pohled do herbáře Jana Černého. Vedle částí balzamovaných těl byla tímto slovem označována také tajuplná látka pocházející z horských svahů, štáva z kořenů neznámé rostliny, ale též prírodnina zemského původu podobná asfaltu, jejíž vlastnosti jsou ovlivněné vlivem nebeských těles. ${ }^{32}$ Harant každopádně slovem mumie označoval balzamovaná těla a znal léčebné účinky spojené s jejich užíváním. Postěžoval si, že Turci uvalili embargo na dovoz mumií do Evropy a připomenul, že kousek mumie vlastnil francouzský král František I., který jej s sebou pro jistotu vozil i na cestách. O Rudolfovi II. napsal, že jeho císařská milost „,celau takovau mumii, totiž celého člověka míti ráćc'، Harant tuto mumii viděl a podle červeně obarvených nehtů

27 K. Harant, Putování, I, s. 51.

28 Tamtéž, s. 50-51.

29 Tamtéž, s. 54.

30 K. Harant, Putování, II, s. 147.

31 Tamtéž, s. 254-255.

32 Jan ČERNÝ, Knieha lékařská, kteráž slove herbář neb zelinář, Norimberk 1517, f. 76v. 
poznal, že pochází z Egypta. ${ }^{33}$ Mumie byla patrně uložena v proslulé pražské kunstkomoře, jak naznačuje její inventář z roku 1619.34

Zajímavé kulturně-historické souvislosti odhaluje také Harantův popis opia, které lze dle jeho slov získat z plodů máku rostoucího i v českých zemích. Domácí opium nicméně dle českého cestovatele nedosahuje takových účinků jako opium makovic ze zemí Předního východu, které je v českém prostředí užívané jako utišující prostředek „,v nesnesitedlné bolesti a dlauhém nespani" “. ${ }^{35} \mathrm{~V}$ muslimském prostředí je ovšem uživáno takřka každodenně a běžně jako prostředek navozující vytoužené stavy blízké halucinacím. Tento zhoubný nešvar se údajně rozšíríl i do zemí sousedících s regiony ovládanými Turky.

Opium tak představuje další doklad pro tvrzení, že Harant ve svém díle popsal exotično v zásadě blízké. Podobně jako v prrípadě italských karanténních zásad, arabských knih židovských lékárníků v Káhiře nebo mumií referoval svým (vzdělaným) čtenářùm vesměs o skutečnostech, které byly i ve střední Evropě známé, chtěné, př́ípadně inspirativní. Jeho cestopis lze $\mathrm{v}$ rámci soudobé česky psané žánrové produkce považovat za dílo mimořádné a cenné i jako výchozí bod v úvahách o renesanci a humanismu ve smyslu kulturních kategorií. Harant se jeví být humanistou nikoliv proto, že se odvážil vydat na dalekou cestou, př́ípadně, že si všímá každodennosti žití v exotických krajinách, nýbrž proto, že ve svém díle nashromáždil značné množství poznatků, často mu známých pouze z knih. Renesanční tón jeho cestopisu je natolik mohutný i proto, že v něm rezonuje poznání veskrze středověké, v němž byl vzdělán jak autor cestopisu, tak jeho čtenáři.

\section{DAVID TOMÍČEK}

\section{Ausgewählte gesundheitswissenschaftliche Aspekte der Reisebeschreibung Christoph Harants von Polschitz und Weseritz}

\section{ZUSAMMENFASSUNG}

Christoph Harant von Polschitz und Weseritz hat in seiner umfangreichen Reisebeschreibung eine Reihe von Phänomenen aufgezeichnet, die mit der Gesundheitspflege bzw. mit der Heilung von Gebrechen zusammenhängen. Kontinuierlich nahm er die Luftqualität wahr, die er in direkten Zusammenhang mit der körperlichen Konstitution der an den besuchten Orten lebenden Menschen stellte. Während er beispielsweise in Brixen oder Venedig die Luft als angenehm und gesundheitsförderlich empfand, äußerte er sich diesbezüglich über die Luft in Alexandria kritisch. Als Ursache für die hier herrschende ungesunde Luft bezeichnete er den Gestank, der sich aus dem mit Nilschlammablagerungen verschmutzten Kanalsystem verbreitete. Im Zusammenhang mit seinem Venedigbesuch beschrieb er einige Grundsätze der lokalen Quarantänemaßnahmen, einschließlich einer vierzigtägigen Isolierung verdächtiger Personen. Diese Art und Weise des Schutzes vor Ansteckung bezeichnete er als italienische Sitte. Mit Interesse besuchte er den berühmten botanischen Garten in Bologna, über den er mit Bewunderung schrieb, dass er für die Bedürfnisse der praktischen Ausbildung der an der örtlichen medizinischen Fakultät Studierenden eingerichtet sei. Über Kairo schrieb er, dass den hiesigen jüdischen Ärzten in ihrer Kenntnis von Heilmitteln wohl kaum jemand konkurrieren könne, denn sie besäßen arabisch verfasste Bücher führender Autoritäten ihres Faches.

33 K. Harant, Putování, II, s. 196.

34 Jan MorÁvek, Nově objevený inventář rudolfinských sbirek na pražském hradě, Památky archeologické - skupina historická, nové řady ročník II., 1932, č. 38, s. 72. K Rudolfově kunstkomoře viz též Becket BUKOvINSKÁ, Kunstkomora Rudolfa II. ve světle inventáře z let 1607-1611, Opera historica 11, 2016, s. 121-147.

35 K. Harant, Putování, II, s. 319. 
Die Einwohner Alexandrias schätzte er als erfahrene Astronomen, die auf den Flachdächern ihrer Behausungen stundenlang mit der Beobachtung des Nachthimmels zubrächten. Harant setzte sich in seinem Werk unter anderem auch mit Opium und Mumien eingehend auseinander. Während er im Falle der Mumien seufzte, dass das türkische Embargo die Einfuhr dieser wertvollen Heilsubstanz nach Europa erschwerte, wertete er den übermäßigen Gebrauch von Opium als verhängnisvolle Unsitte, die sich unglücklicherweise in Europa mit Erfolg verbreite.

Deutsche Übersetzung Wolf B. Oerter

David Tomiček

Katedra historie FF UJEP

Ústav dějin lékařstvi a cizich jazyků 1. LF UK

david.tomicek@ujep.cz 